\title{
FREQUÊNCIA DE LEPTOSPIROSE EM OVINOS ABATIDOS NO MUNICÍPIO DE PATOS, PARAÍBA
}

\section{S.S.S. Higino ${ }^{1}$, S.S. Azevedo ${ }^{1}$, C.J. Alves ${ }^{1}$, S.M. Figueiredo ${ }^{1}$, M.L.C.R. Silva ${ }^{1}$, C.S.A. Batista ${ }^{2}$}

${ }^{1}$ Universidade Federal de Campina Grande, Centro de Saúde e Tecnologia Rural, Unidade Acadêmica de Medicina Veterinária, Av. Universitária, s/nº, CEP 58700-970, Patos, PB, Brasil. E-mail: ssazevedo@cstr.ufcg.edu.br

\section{RESUMO}

Foram colhidas amostras de placenta, ampola do ducto deferente e glândulas vesiculares de 80 ovinos abatidos no matadouro público de Patos, Estado da Paraíba, região Nordeste do Brasil para isolamento de Leptospira spp., bem como amostras de sangue para a pesquisa de anticorpos anti-Leptospira spp. O meio de Ellinghausen-McCullough-Johnson-Harris (EMJH) modificado com a adição de $10 \%$ de soro de coelho foi usado para o isolamento do agente e a técnica de soroaglutinação microscópica para a pesquisa sorológica. Os cultivos foram observados semanalmente por microscopia de campo escuro durante 16 semanas. Seis animais (7,5\%) foram soropositivos na SAM, sendo o sorovar Autumnalis o mais frequente, com cinco soros reagentes, seguido pelo sorovar Icterohaemorragiae, com um soro reagente. Foi isolado micro-organismo morfologicamente similar a Leptospira spp. de uma amostra de ampola do ducto deferente e outra de placenta.

PALAVRAS-CHAVE: Isolamento, Leptospira spp., ovinos, cultivo.

\section{ABSTRACT}

FREQUENCY OF LEPTOSPIROSISIN OVINESLAUGHTEREDINPATOS, PARAÍBA, BRAZIL. Placenta, ampulla of the deferent duct, and seminal vesicle samples were collected from 80 sheep slaughtered in the public slaughterhouse of Patos, Paraíba state, Northeastern region of Brazil, for isolation of Leptospira spp., and blood samples were taken from the same animals to check for the presence of anti-Leptospira spp. antibodies. Ellinghausen-McCullough-Johnson-Harris (EMJH) medium modified with the addition of $10 \%$ rabbit serum was used for the leptospira isolation, while the microscopic agglutination test (MAT) was used to check for the presence of antibodies. The cultures were observed weekly by dark field microscopy for 16 weeks. Six animals $(7.5 \%)$ were seropositive by MAT, the serovar Autumnalis being the most frequent, with 5 reactant sera, followed by the serovar Icterohaemorragiae, with 1 reactant serum. A microorganism morphologically similar to Leptospira spp. was isolated from 1 ampulla of the deferent duct sample and 1 placenta sample.

KEY WORDS: Isolation, Leptospira spp., sheep, culture.

A leptospirose uma doença amplamente difundida no Brasil que acarreta elevados prejuízos econômicos para a pecuária nacional, tendo como principal impacto o comprometimento do desempenhoreprodutivo dos rebanhosacometidos (VASCONCELLos, 1993). A infecção nos ovinos pode se manifestar sob a forma aguda, crônica ou inaparente (FAINE et al., 1999). Os quadros clínicos mais característicos são de septicemia, hemorragia e nefrite, seguida por icterícia, hemoglobinúria, mastite sanguinolenta, retorno ao cio, abortamento nas ovelhas e anemia hemolítica nos cordeiros com morte na primeira semana de vida (CICERONi et al., 2000). No entanto, a forma inaparente é muito mais frequente do que as outras e desperta pouca atenção dos pesquisadores devido à dificuldade no diagnóstico. Por outro lado, do ponto de vista epidemiológico, é uma forma muito importante, uma vez que a introdução de animais com infecção inaparente pode garantir a persistência do agente nos rebanhos acometidos.

O sorovar mais comum em ovinos em todo o mundo é o Hardjo, sendo, portanto, o principal responsável por problemas reprodutivos em ovelhas e de morte de cordeiros (Herrmann et al., 2004). Além desse sorovar, também têm sido descritos outros sorovares, porém com menor frequência, merecendo destaque os sorovares Pomona, Ballum, Bratislava e Grippotyphosa.

${ }^{2}$ Universidade de São Paulo, Faculdade de Medicina Veterinária e Zootecnia, Departamento de Medicina Veterinária Preventiva e Saúde Animal, São Paulo, SP, Brasil. 
O isolamento de leptospiras exerce um papel de relevância indiscutível no controle da infecção, pois permite o conhecimento exato dos diferentes sorovares existentes em determinada região (FREITAS et al., 2004). Desse modo, o objetivo do presente trabalho foi identificar ovinos abatidos no matadouro público do Município de Patos, Estado da Paraíba, infectados por Leptospira spp.

Foram utilizados tratos genital e urinário de 80 ovinos, sendo53 machose27 fêmeas, abatidosnomatadouro público do Município de Patos, Estado da Paraíba, no períodode2005a2006. Tambémforamcolhidasamostras de sangue por punção da veia jugular antes do abate.

Amostras de placenta, ampola do ducto deferente e glândulas vesiculares foram assepticamente colhidas durante o abate dos animais, separadas em sacos de polipropileno estéreis e transportadas ao laboratório em condições de refrigeração (caixa isotérmica com gelo). No laboratório, as amostras foram processadas dentro de três horas após a colheita (THIERMANN, 1983). O meio de EllinghausenMcCullough- Johnson-Harris (EMJH) (Difco-USA), modificado com a adição de $10 \%$ de soro de coelho enriquecido com cloreto de cálcio e cloreto de magnésio (ALVES, 1995), foi preparado em duas formulações, uma sem antibiótico e outra com a adição de 5-fluorouracil (400 mg/ L; Sigma-USA). Foi retirado um fragmento de aproximadamente $1 \mathrm{~g}$ por amostra, cultivado em duplicata no meio de EMJH com antibiótico e incubado a $28^{\circ} \mathrm{C}$ por 24 horas, seguido pela subcultura em duplicata no mesmo meio, contudo, sem antibiótico. As culturas foram observadas semanalmente por microscopia de campo escuro por até 16 semanas (Ellis et al., 1983). Na evidência de crescimento de leptospiras, foi realizada subcultura em duplicata em EMJH modificado sem antibiótico.

O diagnóstico sorológico da leptospirose foi realizado no Laboratório de Zoonoses Bacterianas da Faculdade de Medicina Veterinária e Zootecnia (FMVZ) da Universidade de São Paulo (USP) pela técnica de Soroaglutinação Microscópica (SAM), de acordo com GALTON et al. (1965) e Cole et al. (1973), com uma coleção de antígenos vivos queincluiu os sorovares: Castellonis, Javanica, Tarassovi, Whitcombi,
Australis, Autumnalis, Bataviae, Bratislava, Canicola, Copenhageni, Grippotyphosa, Hardjo, Hebdomadis, Pomona, Icterohaemorrhagiae, Sentot, Wolffi, Pyrogenes, Butembo, Cynopteri, Panama, Shermani, Andamana ePatoc. Os soros foram triados na diluição de 1:100, e aqueles que apresentaram $50 \%$ ou mais de aglutinação foram titulados pelo exame de uma série de diluições geométricas de razão dois. O título do soro foi a recíproca da maior diluição que apresentou resultado positivo. Os antígenos eram examinados ao microscópio de campo escuro, previamente aos testes, a fim de verificar a mobilidade e a presença de autoaglutinação ou de contaminantes.

Em relação ao isolamento de Leptospira spp., em duas amostras (2,5\%) foram isolados micro-organismos morfologicamente similares a Leptospira spp., sendo uma amostra de ampola do ducto deferente e outra de placenta. Os achados de ElLis et al. (1986) ressaltaram a importância do trato genital como sítio de localização de leptospiras. Esses autores conseguiram isolar leptospiras a partir do útero de porcas advindas de propriedades onde a leptospirose estava instalada. Oisolamento de leptospiras viáveis a partir de animais recém-abatidos reforça ainda mais a importância da leptospirose em saúde pública.

Seis animais $(7,5 \%)$ foram soropositivos na SAM. O Autumnalis foi o sorovar mais frequente, com cinco soros reagentes $(6,25 \%)$, seguido pelo sorovar Icterohaemorragiae, com um soro reagente $(1,25 \%)$ (Tabela 1). Frequências inferiores foram encontradas por ZAMORA et al. (1999), que observaram 5,7\% de prevalência para a leptospirose em ovelhas no Chile, com maior predominância dos sorovares Icterohaemorrhagiae, Autumnalis and Hardjo. No entanto, Herrmann et al. (2004), trabalhando com ovinos na região sul do Brasil, encontraram 34,26\% de positividade, com destaque para os sorovares Hardjo (Norma), Sentot, Hardjoprajitno eFortbragg. Essas variações podem estar associadas a fatores relacionados à epidemiologia da doença, que podem afetar o seu comportamento, com destaque para a topografia, região, temperatura, pluviosidade, reservatórios silvestres e domésticos e outros fatores ambientais (Alves et al., 2000).

Tabela 1 - Amostras positivas para o isolamento e para o teste de soroaglutinação microscópica aplicada a leptospirose de ovinos abatidos no matadouro público do Município de Patos, Estado da Paraíba, no período de 2005 a 2006.

\begin{tabular}{ccccc}
\hline $\begin{array}{c}\text { Identificação das } \\
\text { amostras }\end{array}$ & Isolamento & $\begin{array}{c}\text { Soroaglutinação mi- } \\
\text { croscópica }\end{array}$ & Sorovar & Título de anticorpos \\
\hline 6 & + & - & $\ldots$ & $\ldots$ \\
34 & + & - & $\ldots$ & $\ldots$ \\
23 & - & + & Autumnalis & 1600 \\
28 & - & + & Autumnalis & 1600 \\
29 & - & + & Autumnalis & 800 \\
49 & - & + & Autumnalis & 400 \\
54 & - & + & Autumnalis & -100 \\
67 & - & + & Icterohaemorragiae & 200 \\
\hline
\end{tabular}

(-) Negativo; (+) Positivo 
A presença do sorovar Autumnalis causa preocupação, pois não existe imunidade cruzada entre os diferentes sorovares, eno mercado existem as vacinas compostas, basicamente, pelos sorovares Canicola, Icterohaemorrhagiae, Grippotyphosa, Pomona e Hardjo, o que reforça ainda mais a importância da pesquisa continuada no desenvolvimento de novas vacinas contra a leptospirose e a necessidade da inclusão de novos sorovares, visando à elaboração de vacinas mais efetivas e deimunidade mais duradoura. A ocorrência de reação para o sorovar Icterohaemorrhagiae sugere a infecção dos animais pelo contato com ambiente contaminado com urina de roedores, uma vez que o hospedeiro mantenedor desse sorovar é a ratazana (Rattus novergicus) (FAINE et al., 1999).

Os dois animais positivos no isolamento de leptospirasforam negativos naSAM. Embora controverso, a ocorrência desse fato não é única. YASUDA; SANTA RosA (1981), trabalhando com isolamento em cães, isolaram a bactéria em 35 animais a partir do rim, sendo que dentre eles cinco $(14,3 \%)$ apresentavam sorologia negativa para leptospirose. Isso pode ocorrer pelo fato das leptospiras serem antígenos com baixa antigenicidade (ARDUINo et al., 2004), induzindo respostas imunológicas insatisfatórias e por curto período de tempo. Dessa forma, o animal pode estar infectado, porém não apresenta título de anticorpos suficiente para caracterizar uma reação de soroaglutinação positiva.

O possível isolamento de leptospiras obtido no presente trabalho indica que ovinos abatidos no matadouro público de Patos, Estado da Paraíba, podem ser fontes de infecção do agente, expondo os magarefes ao risco ocupacional da doença. As amostras isoladas foram enviadas para laboratório de referência para posterior tipificação dos sorovares.

\section{REFERÊNCIAS}

ALVES, C.J. Influência de fatores ambientais sobre a proporção de caprinos soro-reatores para leptospirose em cinco centros de criação do Estado da Paraíba, Brasil. 1995. 104p. Tese (Doutorado) - Faculdade de Medicina Veterinária e Zootecnia, Universidade de São Paulo, São Paulo, 1995.

ALVES, C.J.; ANDRADE, J.S.L.; VASCONCELLOS, S.A.; MORAIS, Z.M.; AZEVEDO, S.S.; SANTOS, F.A. Avaliação dos níveis de aglutininas anti-leptospira em cães no município de Patos-PB, Brasil. Revista Brasileira de Ciência Veterinária, v.7, n.2, p.17-21, 2000.

ARDUINO, G.G.C.; GIRIO, R.J.S., FREIRE, M.M. Anticorpos contra Leptospira spp. em bovinos leiteiros vacinados com bacterina polivalente comercial: perfil sorológico frente a dois esquemas de vacinação. Ciência Rural, v.34, n.3, p.865-871, 2004.
CICERONI, L.; LOMBARDO, D.; PINTO, A.; CIARROCCHI, S.; SIMEONI, J. Prevalence of antibodies to Leptospira serovars in sheep and goats in Alto AdigeSouth Tyrol. Journal of Veterinary Medicine. Series B, v.47, n.5, p.217-223, 2000.

COLE, J.R.; SULZER, C.R.; PULSSELY, P.R. Improved microtechnique for the leptospiral microscopic agglutination. Applied Microbiology, v.5, n.6, p.976-980, 1973.

ELLIS, W.A.; BRYSON, D.G.; NEILL, S.D.; MCPARLAND, P.J.; MALONE, F.E. Possible involvement of leptospires in abortion, stillbirths and neonatal deaths in sheep. Veterinary Record, v.112, n.13, p.291-293, 1983.

ELLIS, W.A.; MCPARLAND, P.J.; BRYSON, D.G.; THIERMANN, A.B.; MONTGOMERY, J. Isolation of leptospiroses from the genital tract and kidneys of aborted sows. Veterinary Record, v.118, n.11, p.294-295, 1986.

FAINE, S.; ADLER, B.; BOLIN, C.; PEROLAT, P. Leptospira and leptospirosis. Melbourne: MediSci, 1999. 272p.

FREITAS, J.C.; SILVA, F.; OLIVEIRA, R.C. Isolamento de Leptospira spp. de cães, bovinos e suínos naturalmente infectados. Ciência Rural, v.34, n.3, p.853-856, 2004.

GALTON, M.M.; SULZER, C.R.; SANTA ROSA, C.A.; FIELDS, M.J. Aplication of a microtechnique to the aglutination test for leptospiral antibodies. Applied Microbiology, v.13, p.81-85, 1965.

HERRMANN, G.P.; LAGE, A.P.; MOREIRA, E.C. Soroprevalência de aglutininas anti-Leptospira spp. em ovinos nas Mesorregiões Sudeste e Sudoeste do Estado Rio Grande do Sul, Brasil. Ciência Rural, v.34, n.2, p.443448, 2004.

THIERMANN, A.B. Bovine leptospirosis: Bacteriologic versus serologic diagnosis of cows at slaughter. American Journal of Veterinary Research., v.44, n.12, p.22442245, 1983.

VASCONCELLOS, S.A. Leptospirose animal. In: ENCONTRO NACIONAL EM LEPTOSPIROSE, 3., 1993, Rio de Janeiro, RJ. Resumos. Rio de Janeiro: 1993. p.62-66.

YASUDA, P.H.; SANTA ROSA, C.A. Correlação entre soroaglutinação e isolamento de leptospiras em cães. Revista de Microbiologia, v.12, n.2, p.35-37, 1981.

ZAMORA, J.; RIEDEMANN, S.; TADICH, N.A. A serological survey of leptosirosis in sheep in chile. Revista Latinoamericana de Microbiologia, v.41, n.2, p.73-76, 1999.

Recebido em 5/5/09

Aceito em 15/7/10 